\title{
Allelopathic effect of Sorghum bicolor powder and fresh Chenopodium album water extract on seedling growth of sunflower under the agro-climatic conditions of Tandojam, Sindh-Pakistan
}

Kamran Razzaque Kalwar ${ }^{1}$, Abdul Haleem Sial ${ }^{1}$, Ayaz Latif Siyal ${ }^{2 *}$, Manthar Ali Sahito ${ }^{1}$, Aneel Ahmed Korejo ${ }^{1}$, Fateh Muhammad Baloch ${ }^{3}$, Babar Sultan Mengal $^{1}$ and Khalil Ahmed Brohi ${ }^{1}$

1. Department of Agronomy, Faculty of Crop Production, Sindh Agriculture University Tandojam, Pakistan

2. Department of Plant Breeding and Genetics, Sindh Agriculture University, Tandojam Sindh, Pakistan

3. Social Science Institute, Agriculture Research Institute, Quetta (PARC), Pakistan

*Corresponding author's email: latifayazsiyal@gmail.com

\section{Citation}

Kamran Razzaque Kalwar, Abdul Haleem Sial, Ayaz Latif Siyal, Manthar Ali Sahito, Aneel Ahmed Korejo, Fateh Muhammad Baloch, Babar Sultan Mengal and Khaleel Ahmed Brohi. Allelopathic effect of Sorghum bicolor powder and fresh Chenopodium album water extract on seedling growth of sunflower under the agro-climatic conditions of Tandojam, Sindh-Pakistan. Pure and Applied Biology. Vol. 11, Issue 3, pp734-743.

http://dx.doi.org/10.19045/bspab.2022.110074

Received: 21/05/2021 Revised: 26/07/2021

Accepted: 10/10/2021

Online First: $05 / 11 / 2021$

\section{Abstract}

The study was carried out during 2013 to examine the allelopathic effect of Sorghum bicolor powder and fresh Chenopodium album water extract on seedling growth of sunflower. The experiment was conducted in a 3 replicated completely randomized design (CRD), using sunflower variety $\mathrm{HO}^{-1}$. Seven treatments were examined which included: $\mathrm{T}_{1}=$ Control (untreated), $\mathrm{T}_{2}=$ Fresh C. album water extract concentration $30 \%, \mathrm{~T}_{3}=$ S. bicolor Powder water extract concentration 30\%, $\mathrm{T}_{4}=$ Fresh C. album+ Powder S. bicolor WEC $30+30 \%, \mathrm{~T}_{5}=$ Fresh $C$. album + S. bicolor Powder WEC $60+60 \%, \mathrm{~T}_{6}=$ Fresh $C$. album water extract concentration $100 \%$ and $\mathrm{T}_{7}=S$. bicolor Powder water extract concentration $100 \%$. The results revealed that germination of seed $(\%)$, length of $\operatorname{shoot}(\mathrm{cm})$, length of $\operatorname{root}(\mathrm{cm})$, fresh weight of shoot $(\mathrm{g})$, fresh weight of $\operatorname{root}(\mathrm{g})$, dry weight of shoot $(\mathrm{mg})$ and dry weight of $\operatorname{root}(\mathrm{mg})$ were significantly affected by allelopathtic effects $S$. biclor and $C$. album extracts. The seed treatment with $S$. bicolor powder water extract concentration (100\%) resulted in the lowest germination of seed of sunflower $(56.51 \%)$, length of shoot $(8.82 \mathrm{~cm})$, length of root $(1.060 \mathrm{~cm})$, fresh weight of shoot $(5.947 \mathrm{~g})$, fresh weight of root $(0.6067 \mathrm{~g})$, dry weight of shoot $(610.00 \mathrm{mg})$, and dry weight of root $(95.00 \mathrm{mg})$. The allelopathic effect of Fresh $C$. album water extract concentration (100\%), ranked second, Fresh C. album+ S. bicolor Powder WEC $60+60 \%$ ranked $3^{\text {rd }}$, Fresh $C$. album+ Powder S. bicolor WEC $30+30 \%$ ranked $4^{\text {th }}, S$. bicolor Powder water extract concentration $30 \%$ ranked $5^{\text {th }}$, Fresh $C$. album water extract concentration $30 \%$ ranked $6^{\text {th }}$ and control ranked $7^{\text {th }}$ for all the parameters investigated. It is concluded that $C$. album+ Powder $S$. bicolor extracts could effectively be used not only to suppress the weeds in sunflower.

Keywords: Alleleopthic; Chenopodium album; Seedling growth; Sorghum bicolor; Water extract 


\section{Introduction}

Sunflower (Helianthus annuus L.) is a seed grown twice a year for short seasons, with a development period of 19-120 days. It blends well into current cropping systems and can be cultivated without any big crop being replaced $[1,2]$. Sunflower produced 3.255 million tonnes of edible oil annually, including 0.507 million tones of local production and 2.748 million tons of import share [3]. Sunflower has the capacity to fill the difference between edible oil demand and supply and is well suited to Pakistan's agro-ecological conditions, which were introduced in Pakistan in the 1960s and have become the country's main oilseed crop [4].

Germination of sorghum and sunflower species decreased with a rise in extract concentration and germination was 35 and 20 percent respectively in sunflower and sorghum with 10 percent extract concentration. Increased concentration also reduced shoot and root duration and dry weight [5]. From numerous sunflower cultivars, more than 200 natural allelopathic compounds have been isolated. Reduction of the radical and hypocotyl duration of mustard seedling induced by sunflower leaf extracts [6] has shown that sunflower components greatly inhibit the germination of Solanum nigrum L. Being a seed of brief period and economic value. Weed control is one of the key components of crop husbandry toward potential yields and is the main cause of poor crop yields per unit area. Decrease in cotton yields of 16-53 per cent due to weed infestation, recorded by Baloglu et al. [7]. Established strategies for weed control are either costly or risky. Chemical weed control can trigger contamination, whereas hand weeding is labour intensive and expensive.

Allelopathy is a biological process in which one or more biochemicals that impair the development, life, and reproduction of other species are created by an organism. These biochemicals are classified as allelochemicals and may have consequences on the target species that are favourable (positive allelopathy) or harmful (negative allelopathy). Allelochemicals are a subset of secondary metabolites [8] which are not necessary for the allelopathic organism's metabolism (i.e. growth, development and reproduction). An significant aspect of plant defence against herbivory is allelochemicals with harmful allelopathic results [9]. Hesammi [10] observed that allelopathy, by the release of chemicals, relates to the overt or indirect influence of plants on other plants and plays an important role in many agro-ecosystems. In both natural and human-made environments, allelopathic interactions have been documented to play a crucial role. Similarly, Baloglu et al. [7] observed that allelopathy is a significant element that helps to assess the distribution and abundance of organisms within populations. In the success of several introduced plants, allelopathy is often helpful; spotted knapweed, Centaurea maculosa, Asteraceae family, Nut sedge, Cyperus sp. The Cyperaceae family.

Sorghum is an aggressive and stubborn weed that thrives in troubled soils [11]. Besides the competitive potential of Sorghum halepense, the development of allelopathic substances is well known [12, 13]. Osmotic pressure is isolated from the allelopathic impact of Sorghum halepense extracts and maize (Zea maize) production plants. Mahmood et al. [14] found that wild sorghum extracts had important and different allopathic effects on the germination of maize grain. Mudassir et al. [15] confirmed that germinating, seeding and growing seedlings measured the resistance of Sorghum halepense (Johnsongrass). The allelopathic impact of Sorghum halepense's leaf and stem on wheat seedling length growth was recorded by [16]. Newman [17] suggested that it is 
feasible to use allelopathic responses as a bioherbicide for the allelopathic impact of Sorghum halepense leaf and stem. The current research was planned to investigate the influence of Johnsongrass (Sorghum halepense L.) allelopathic weed on the growth and seedling of maize.

\section{Materials and Methods}

The laboratory experiment was conducted at seed testing laboratory, Agronomy Department, Sindh Agriculture University Tandojam. Experiment was performed in CRD with three replicates. Variety HO-1 was tested for various sunflower traits. The sorghum bicolor powder concentration was prepared by using $300 \mathrm{ml}$ distilled water and 30 gram sunflower powder. The 50 gram of fresh chenopodium album plants was soaked in $300 \mathrm{ml}$ distilled water for 12 hours then sunflower seeds soaked in calculated allelopathic concentration percentage basis for 2.5 hours. The seeds sown in Petridishes and was kept in germinator for 25 days. The data of all parameters was taken. The treatments are given under:

\section{Treatments}

(water extract concentrations Chenopodium album and Sorghum bicolour) $=7$

$\mathrm{T}_{1}=$ Control (untreated)

$\mathrm{T}_{2}=$ Fresh $C$. album water extract concentration $30 \%$

$\mathrm{T}_{3}=\mathrm{S}$. bicolor Powder water extract concentration $30 \%$

$\mathrm{T}_{4}=$ Fresh C. album + Powder S. bicolor WEC $30+30 \%$

$\mathrm{T}_{5}=$ Fresh C. album + S. bicolor Powder WEC $60+60 \%$

$\mathrm{T}_{6}=$ Fresh C. album water extract concentration $100 \%$

$\mathrm{T}_{7}=\mathrm{S}$. bicolor Powder water extract concentration $100 \%$

\section{Statistical analysis}

Data was obtained were utilized for the analysis by ANOVA method using Statistix 8.1 version.

\section{Results and Discussions}

Germination of seed (\%)

The result for germination \% has affected by allelopathic concentrations of fresh Lambs quarter (C. album L.) and Sorghum ( $S$. bicolor L.) powder water extract concentrations on sunflower. The (Fig. 1) showed statistically significant for germination $\%$. The results for germination of seed showed significant response towards different allelopathic water extract concentrations. The maximum mean germination of seed \% (82.44 and 80.72) was recorded in control (non treated) and @ application of fresh C. album water extract concentration $30 \%$ followed by (78.57 and 75.150) @ applications of S. bicolor Powder water extract concentration 30\% Fresh $C$. album+ Powder S. bicolor WEC 30+30\% and the minimum germination of seed $\%$ (56.51) was observed @ allelopathic applications of $S$. bicolor powder water extract concentration $100 \%$, respectively. Further results revealed that the allelopathic applications of Fresh C. album+ S. bicolor Powder WEC 60+60\% and fresh C. album water extract concentration $100 \%$ also showed significant response to germination of seed $\%$ of sunflower.

\section{Length of shoot $(\mathrm{cm})$}

The result for length of shoot $(\mathrm{cm})$ has affected by allelopathic concentrations of fresh Lambs quarter (Chenopodium album L.) and Sorghum (Sorghum bicolor L.) powder water extract concentrations on sunflower. The (Fig. 2) showed statistically significant for length of shoot $(\mathrm{cm})$. The results for sunflower plant length of shoot (cm) showed significant response towards different allelopathic water extract concentrations. The maximum mean length of shoot $\mathrm{cm}$ (23.44) was recorded in control (nontreated) followed by (21.82) length of shoot cm @ application of fresh C. album water extract concentration $30 \%$ whereas the minimum length of shoot cm (8.820) @ 
allelopathic application of fresh $C$. album water extract concentration $100 \%$, respectively. The results further revealed that the allelopathic water extract concentrations applications $S$. bicolor powder water extract concentration $30 \%$, fresh C. album+ Powder S. bicolor WEC $30+30 \%$, Fresh C. album + S. bicolor powder WEC $60+60 \%$ and fresh $C$. album water extract concentration $100 \%$ were showed significant response to sunflower length of shoot $\mathrm{cm}$.

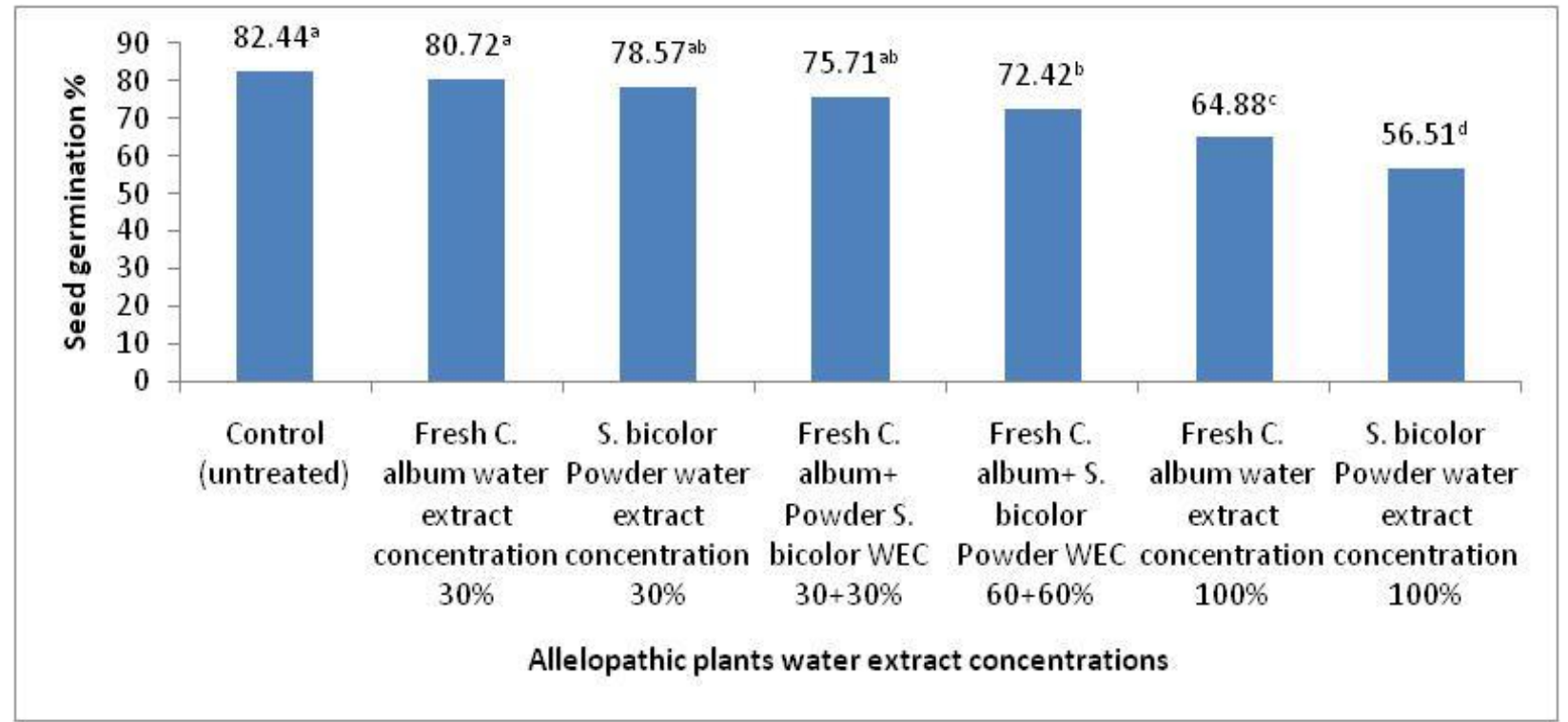

Means sharing different superscripts indicates significant difference at $\mathrm{p}<0.05$.

Figure 1. Effect of allelopathic plants water extract concentrations on germination of seed (\%) of sunflower

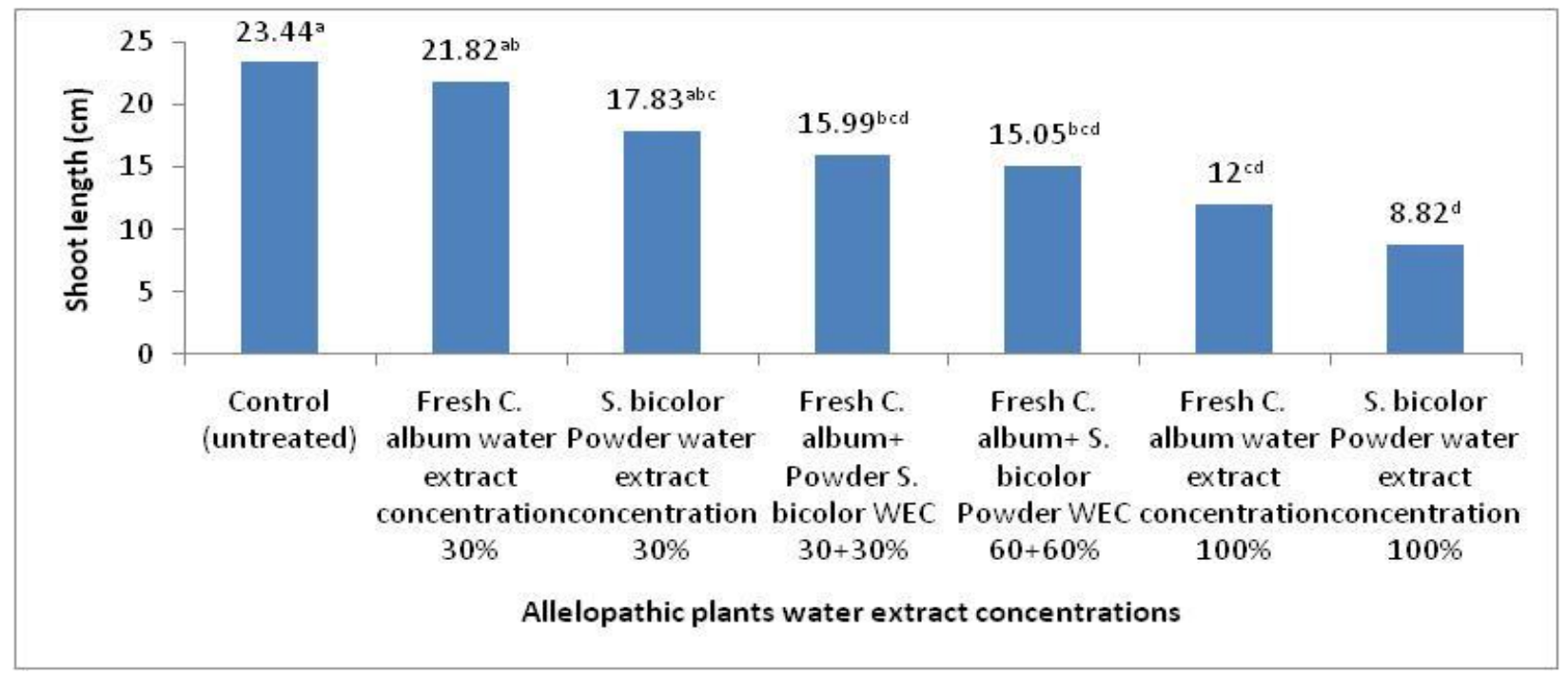

Means sharing different superscripts indicates significant difference at $\mathrm{p}<0.05$.

Figure 2. Effect of allelopathic plants water extract concentrations on length of shoot $(\mathrm{cm})$ of sunflower 


\section{Length of root $(\mathrm{cm})$}

The result for length of root $(\mathrm{cm})$ has affected by allelopathic concentrations of fresh Lambs quarter (Chenopodium album L.) and Sorghum (Sorghum bicolor L.) powder water extract concentrations on sunflower. The (Fig. 3) showed statistically significant for length of root $(\mathrm{cm})$. The results for sunflower plant length of root (cm) showed significant response towards different allelopathic water extract concentrations. The maximum mean length of root $\mathrm{cm}$ (5.843 and 5.657) was recorded in control (nontreated) and fresh C. album water extract concentration $30 \%$ followed by (4.830) and the minimum values for length of root cm (1.060) was observed @ allelopathic water extract concentration applications of $S$. bicolor Powder water concentration extract $100 \%$. The results further revealed that the allelopathic water extarc concentration viz. Fresh $C$. album+ Powder S. bicolor WEC 30+30\%, Fresh $C$. album+ S. bicolor Powder WEC 60+60\% and Fresh $C$. album water extract concentration $100 \%$ also showed significant response to length of root $\mathrm{cm}$ of sunflower.

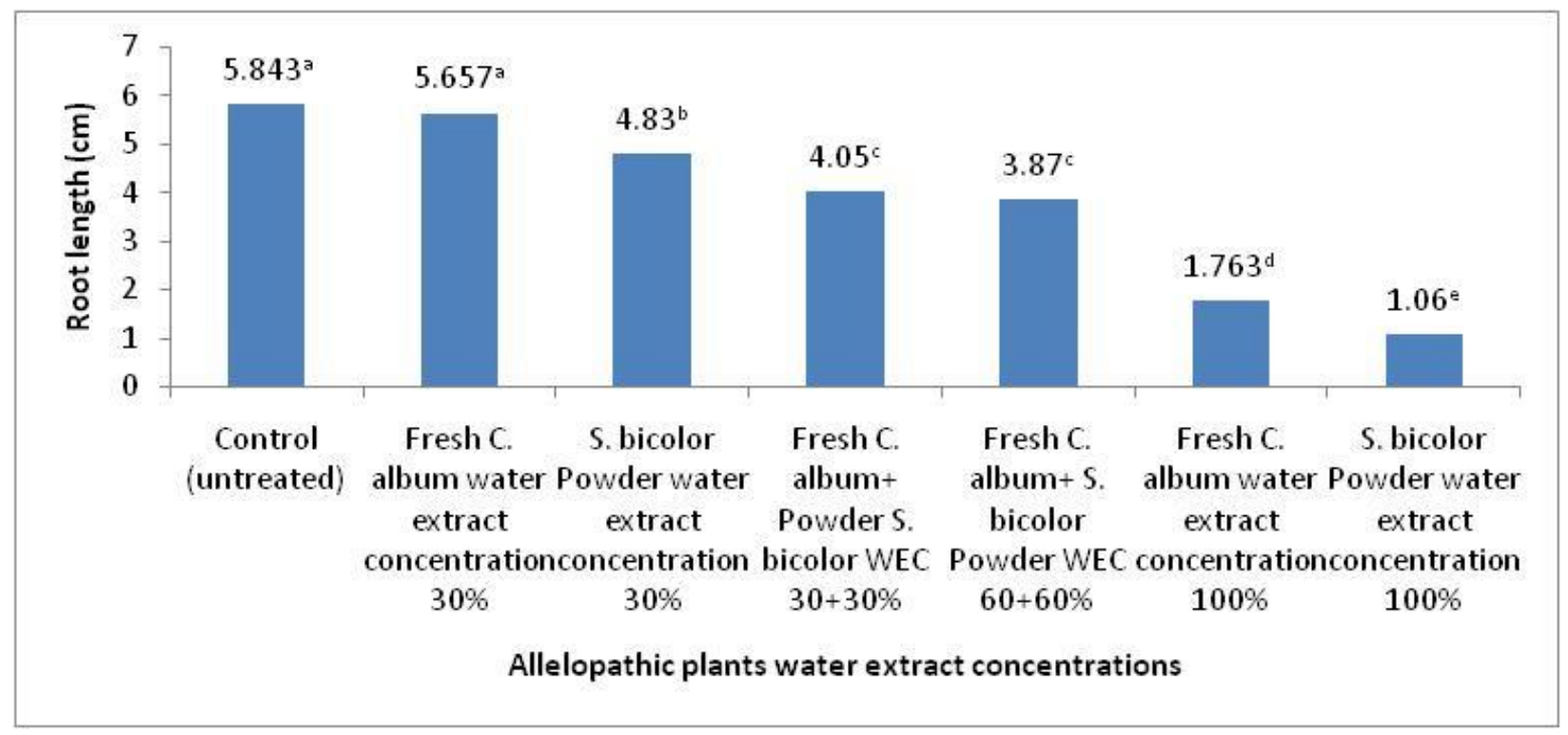

Means sharing different superscripts indicates significant difference at $\mathrm{p}<0.05$.

Figure 3. Effect of allelopathic plants water extract concentrations on length of root (cm) of sunflower

\section{Fresh weight of shoot (g)}

The result for fresh weight of shoot $(\mathrm{g})$ has affected by allelopathic concentrations of fresh Lambs quarter (Chenopodium album L.) and Sorghum (Sorghum bicolor L.) powder water extract concentrations on sunflower. The (Fig. 4) showed statistically significant for fresh weight of shoot $(\mathrm{g})$. The results for fresh weight of shoot $(\mathrm{g})$ showed significant response to different allelopathic water extract concentrations. The maximum mean fresh weight of shoot $\mathrm{g}$ (15.47) was recorded in control (nontreated) followed by (12.90) @ applications of fresh C. album water extract concentration $30 \%$ and the minimum values for fresh weight of shoot $\mathrm{g}$ (5.947) was observed @ allelopathic water extract concentration applications of $S$. bicolor powder water concentration extract $100 \%$, respectively. Further results revealed that other allelopathic concentrations viz. $S$. bicolor Powder water extract concentration 
30\%, Fresh C. album+ Powder S. bicolor WEC 30+30\%, Fresh C. album+ S. bicolor Powder WEC $60+60 \%$ and fresh C. album water extract concentration $100 \%$ showed significant response to fresh weight of shoot (g) of sunflower.

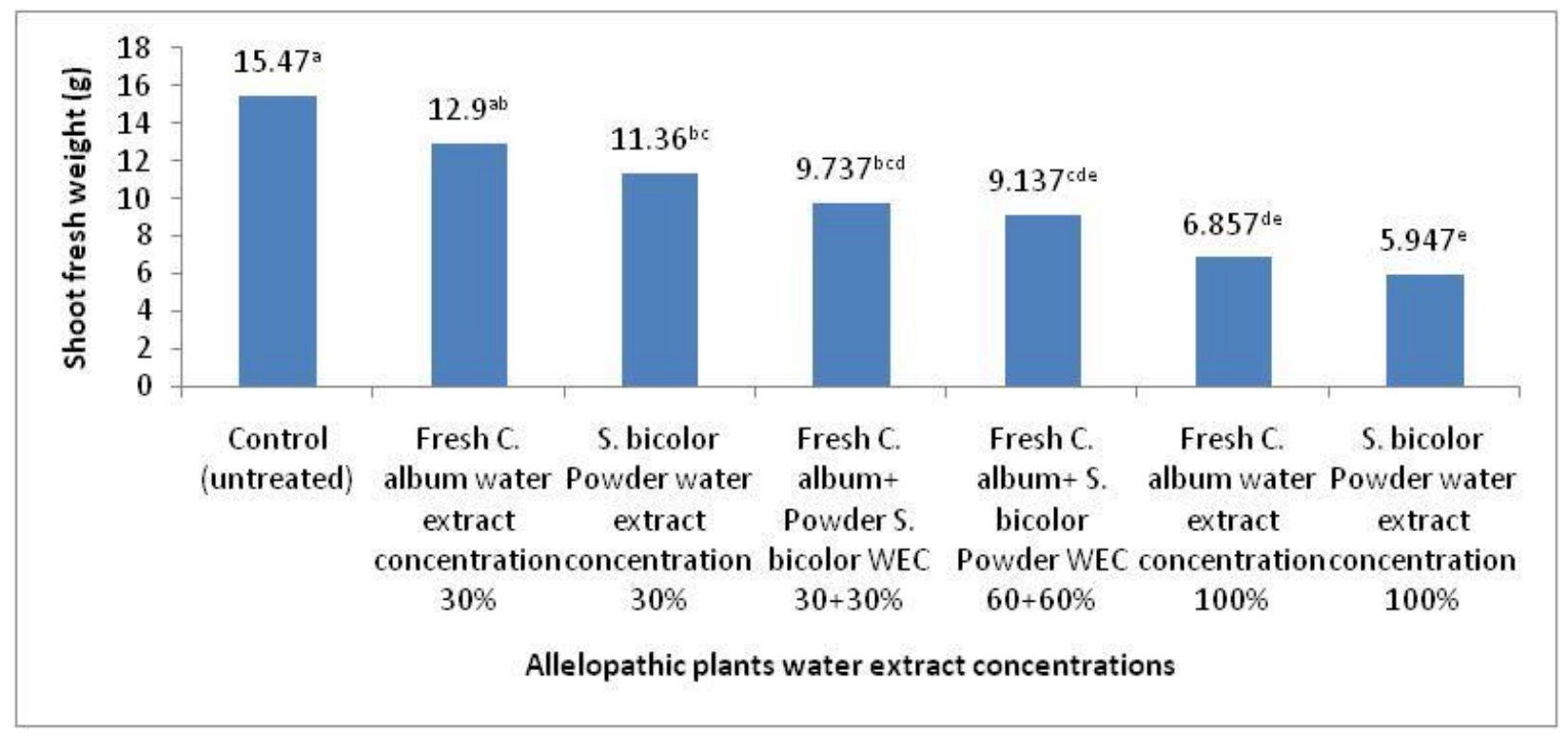

Means sharing different superscripts indicates significant difference at $\mathrm{p}<0.05$.

Figure 4. Effect of allelopathic plants water extract concentrations on fresh weight of shoot (g) of sunflower

\section{Fresh weight of root $(\mathrm{g})$}

The result for fresh weight of root $(\mathrm{g})$ has affected by allelopathic concentrations of fresh Lambs quarter (Chenopodium album L.) and Sorghum (Sorghum bicolor L.) powder water extract concentrations on sunflower. The (Fig. 5) showed statistically significant for fresh weight of root $(\mathrm{g})$. The results for fresh weight of root $(\mathrm{g})$ showed significant response to different allelopathic water extract concentrations. The maximum mean fresh weight of root $g(0.9067)$ was recorded in control (nontreated) followed by (0.7833) @ applications of fresh C. album water extract concentration $30 \%$ and the minimum value for fresh weight of root $\mathrm{g}$ (0.6067) was observed @ allelopathic water extract concentration applications of $S$. bicolor powder water concentration extract $100 \%$, respectively. Further results revealed that other allelopathic concentrations viz. $S$. bicolor Powder water extract concentration
30\%, Fresh C. album+ Powder S. bicolor WEC 30+30\%, Fresh C. album+ S. bicolor Powder WEC $60+60 \%$, Fresh C. album water extract concentration $100 \%$ and $S$. bicolor Powder water extract concentration $100 \%$ were showed non-significant response to each other for fresh weight of root (g), respectively.

Dry weight of shoot (mg)

The result for dry weight of shoot (mg) has affected by allelopathic concentrations of fresh Lambs quarter (Chenopodium album L.) and Sorghum (Sorghum bicolor L.) powder water extract concentrations on sunflower. The (Fig. 6) showed statistically significant for dry weight of shoot $(\mathrm{mg})$. The results for dry weight of shoot (mg) showed significant response to different allelopathic water extract concentrations. The maximum mean dry weight of shoot $\mathrm{mg}$ (894.0) was recorded in control (nontreated) followed by (812.0) @ applications of fresh 
C. album water extract concentration $30 \%$ and the minimum value for dry weight of shoot mg (610.0) was recorded @ allelopathic water extract concentration applications of $S$. bicolor powder water concentration extract $100 \%$. Further results revealed that other allelopathic concentrations viz. S. bicolor Powder water extract concentration $30 \%$, Fresh C. album+ Powder S. bicolor WEC 30+30\%, Fresh $C$. album+ S. bicolor Powder WEC 60+60\%, Fresh $C$. album water extract concentration $100 \%$ and S. bicolor Powder water extract concentration $100 \%$ were showed nonsignificant response to each other for dry weight of shoot (mg), respectively.

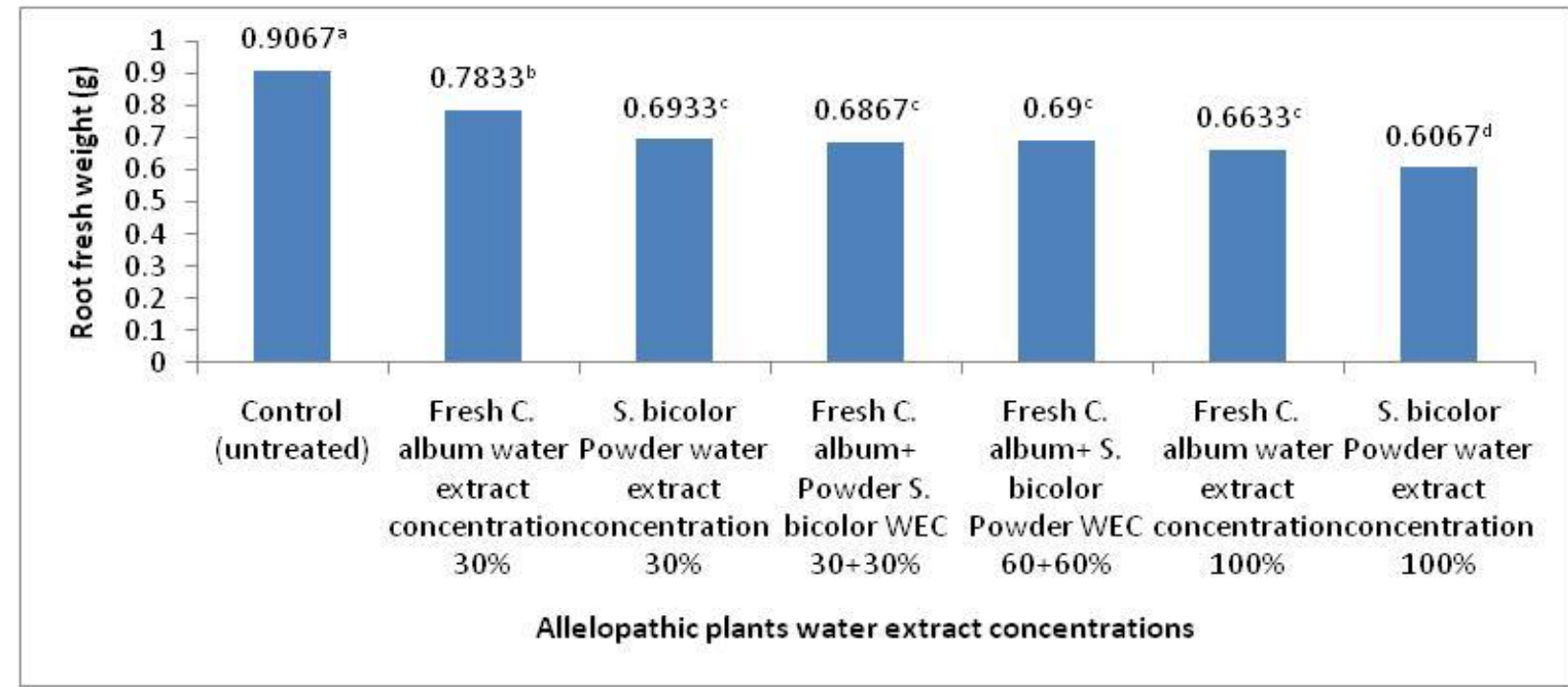

Means sharing different superscripts indicates significant difference at $\mathrm{p}<0.05$.

Figure 5. Effect of allelopathic plants water extract concentrations on fresh weight of root (g) of sunflower

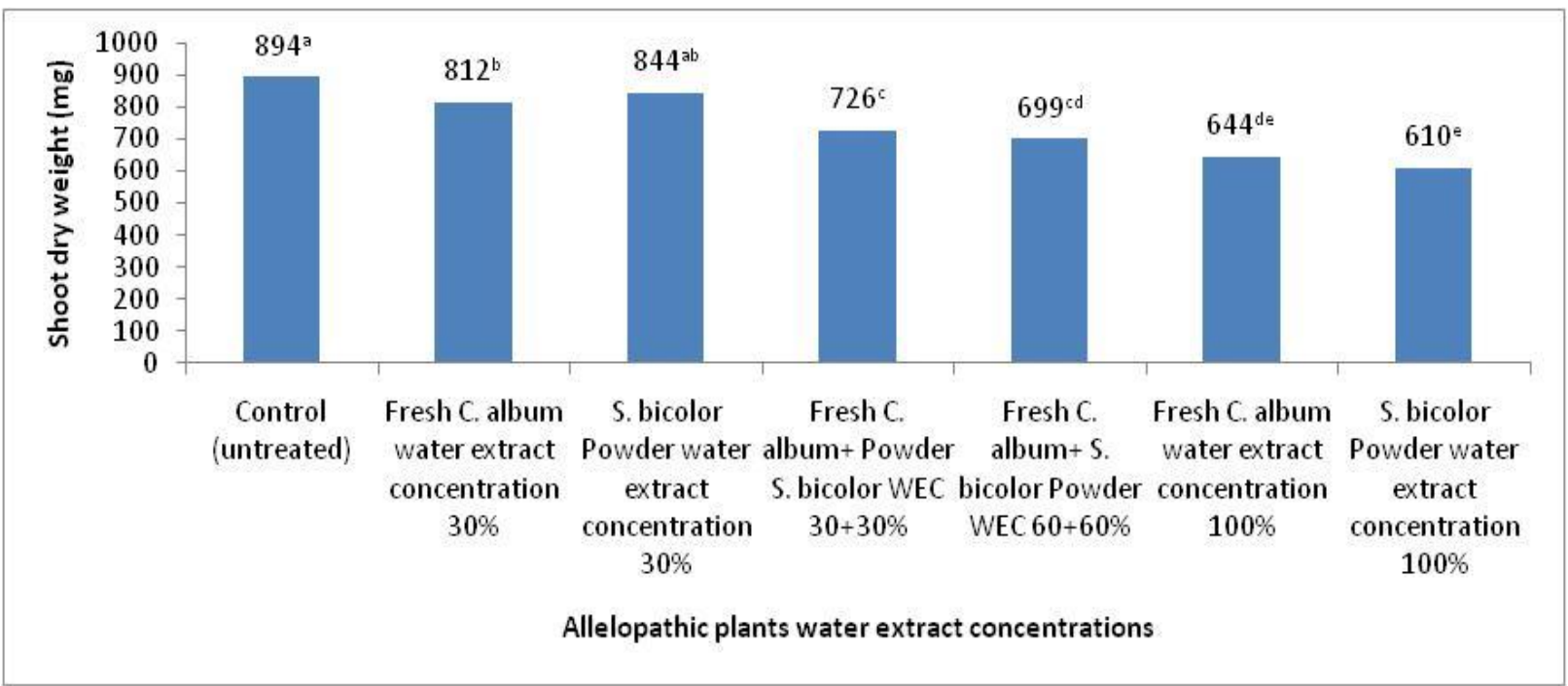

Means sharing different superscripts indicates significant difference at $\mathrm{p}<0.05$.

Figure 6. Effect of allelopathic plants water extract concentrations on dry weight of shoot (mg) of sunflower 


\section{Dry weight of root (mg)}

The result for dry weight of root $(\mathrm{mg})$ has affected by allelopathic concentrations of fresh Lambs quarter (Chenopodium album L.) and Sorghum (Sorghum bicolor L.) powder water extract concentrations on sunflower. The (Fig. 7) showed statistically significant for dry weight of root $(\mathrm{mg})$. The results for dry weight of shoot (mg) showed significant response to different allelopathic water extract concentrations. The maximum mean dry weight of root mg (293.0) was recorded in control (nontreated) followed by (227.0)@ applications of fresh C. album water extract concentration $30 \%$ and the minimum value for dry weight of root $\mathrm{mg}$ (95.00) was recorded @ allelopathic water extract concentration applications of $S$. bicolor powder water concentration extract $100 \%$. Further results revealed that other allelopathic concentrations viz. S. bicolor Powder water extract concentration 30\%, Fresh C. album+ Powder S. bicolor WEC $30+30 \%$, Fresh C. album+ S. bicolor Powder WEC $60+60 \%$, Fresh C. album water extract concentration $100 \%$ and $S$. bicolor Powder water extract concentration $100 \%$ were showed non-significant response to each other for dry weight of root $(\mathrm{mg})$, respectively.

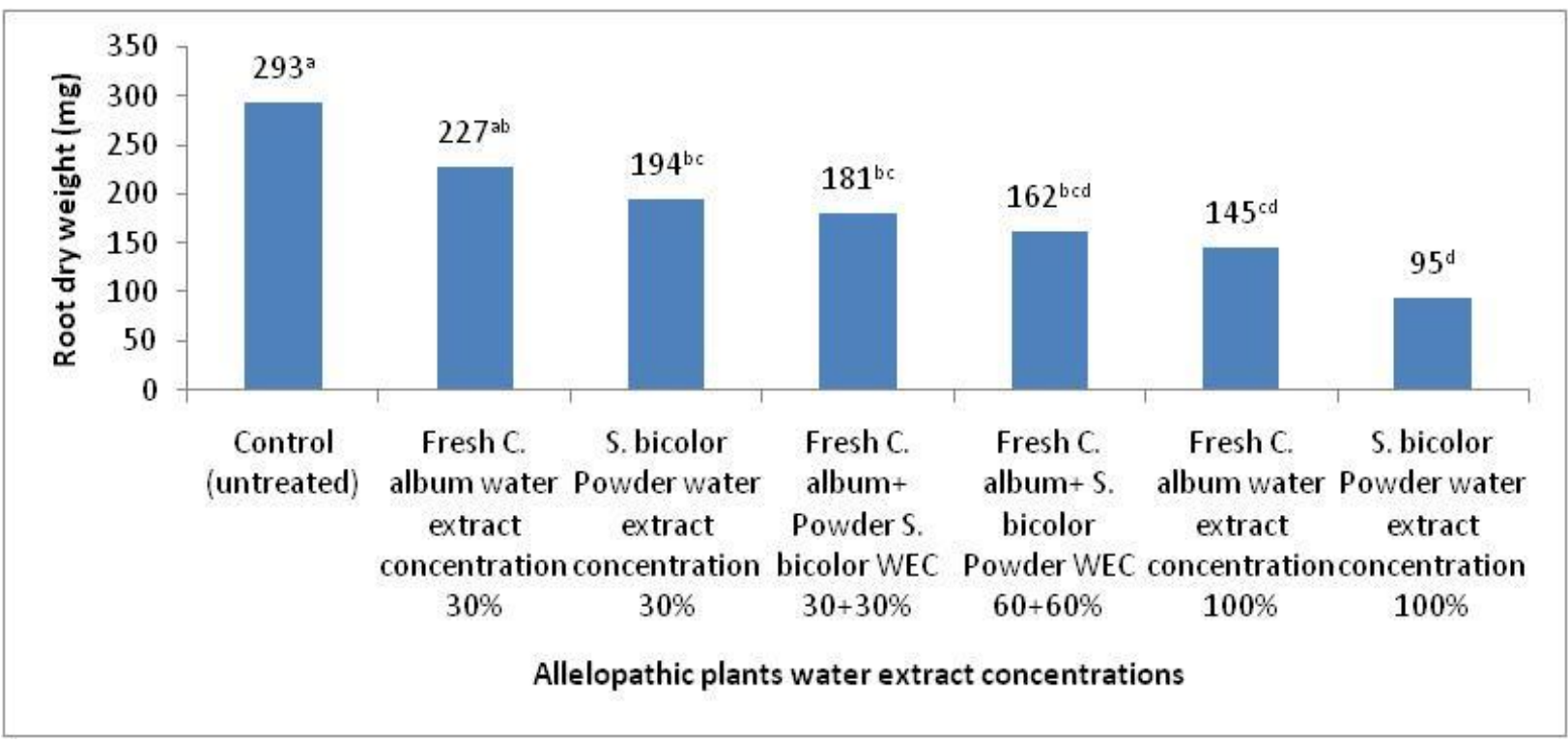

Means sharing different superscripts indicates significant difference at $\mathrm{p}<0.05$.

Figure 7. Effect of allelopathic plants water extract concentrations on dry weight of root (mg) of sunflower

\section{Discussion}

The present study showed that germination of seed, length of shoot, length of root, fresh weight of shoot, fresh weight of root, dry weight of shoot and dry weight of root were significantly affected by allelopathtic effects $S$. biclor and C. album extracts. The seed treatment with S. bicolor Powder water extract concentration $(100 \%)$ resulted in the lowest germination of seed of sunflower $(56.51 \%)$, length of shoot $(8.82 \mathrm{~cm})$, length of root $(1.060$ $\mathrm{cm})$, fresh weight of shoot $(5.947 \mathrm{~g})$, fresh weight of root $(0.6067 \mathrm{~g})$, dry weight of shoot $(610.00 \mathrm{mg})$, and dry weight of root $(95.00 \mathrm{mg})$. The allelopathic effect of Fresh C. album water extract concentration (100\%), ranked second, Fresh C. album+ S. bicolor Powder WEC $60+60 \%$ ranked $3^{\text {rd }}$, Fresh C. album+ Powder $S$. bicolor WEC $30+30 \%$ ranked $4^{\text {th }}, S$. bicolor Powder water extract concentration $30 \%$ ranked $5^{\text {th }}$, Fresh $C$. album water extract concentration $30 \%$ ranked $6^{\text {th }}$ and control ranked $7^{\text {th }}$ for all the 
parameters investigated. It is concluded that $C$. album+ Powder S. bicolor extracts could effectively be used not only to suppress the weeds in sunflower. These observations are compatible with those of Hesammi [10], which suggested that wild sorghum extracts had important and different allopathic effects on the germination of maize grain. Butnariu [9] confirmed that germinating, seeding, and increasing seedlings evaluated the resistance of Sorghum halepense (Johnsongrass). Nouri et al. [18] documented the allelopathic impact of $S$. halepense leaf and stem on wheat seedling length growth. Siyal et al. [19] suggested that as a bioherbicide, allelopathic responses to the allelopathic impact of $S$. halepense leaf and stem may be used. Similarly, Mahmood et al. [14] evaluated allelopathic crop water extracts against sunflower using aqueous sorghum extracts ( $S$. bicolor L.), and discovered that the application of sunflower + sorghum + mulberry extracts combined with Atlantis 3.6 WG @ 7.20 $\mathrm{g}$ a.s/ha demonstrated a greater reduction in overall weed density $(86 \%)$ and total dry weight of marijuana ( 88 percent). Maximum grain yield (2.90 $\mathrm{t} \mathrm{ha}^{-1}$ ), which was $36 \%$ higher than control $\left(2.13 \mathrm{t} \mathrm{ha}^{-1}\right)$ and $3.94 \%$ higher than the prescribed herbicide dosage, was also obtained with the same treatment $\left(2.79 \mathrm{tha}^{-1}\right)$. The results also revealed the superiority of this procedure with a higher net return of Rs. 71322 per hectare and a marginal return rate of 4221 percent. Mudassir et al. [15] recorded that the reduction in fresh weight and dry weight of all herbicide weeds was maximum (41\%) whereas most allelopathic crops leachate therapies greatly reduced dry weight of total weeds by $15 \%$. Sedigheh et al. [20] observed that Chenopodium album, S. halepense, helped minimize plant germination of seeds and seedling development was more extreme. Comparison of extract results with polyethylene glycol showed that the osmotic pressure of the extract was related to the reduction of germination of seed and seedling development in Johnsongrass and Common lambsquarter, while inhibition of germination of seed was due to allelochemicals in Redroot pigweed and maize. Baloglu et al. [7] stated that $S$. biclor application was all-allelopathic to sunflower weeds and remained successful in reducing weed germination and growth, checked by Siyal [21]. Halepense's used its extract as an allelopathic plant and stated that the germination was not impaired by either of the extracts examined, but the existence of tropane alkaloids inhibited development. At higher alkaloid concentrations, extracts had an effect. Seedlings from $S$. Halepense produced signs of toxicity in the presence of alkaloid extracts, but some chlorotic and necrotic areas were observed in the biotest of the flower extract. Soufan and Almouemar [22] stated that wild sorghum allopathic effects resulted in decreased germination and fresh and dry weight of the root/shoot under field conditions.

\section{Conclusion}

The allelopathic effect of Fresh C. album water extract concentration (100\%), ranked second, Fresh $C$. album+ S. bicolor Powder WEC $60+60 \%$ ranked $3^{\text {rd }}$, Fresh $C$. album+ Powder $S$. bicolor WEC $30+30 \%$ ranked $4^{\text {th }}$, S. bicolor Powder water extract concentration $30 \%$ ranked $5^{\text {th }}$, Fresh $C$. album water extract concentration $30 \%$ ranked $6^{\text {th }}$ and control ranked $7^{\text {th }}$ for all the parameters investigated. It is concluded that $C$. album+ Powder S. bicolor extracts resulted optimum seedling growth of sunflower and could effectively be used to suppress the weeds in sunflower.

\section{Authors' contributions}

Conceived and designed the experiments: KR Kalwar \& AH Sial, Performed the experiments: KR Kalwar \& FM Baloch, Analyzed the data: MA Sahito, AA Korejo \& BS Mengal, Contributed materials/ analysis/ tools: AL Siyal, KA Brohi \& FM Baloch, Wrote the paper: AL Siyal.

\section{References}

1. Shah NA, Khalil MA, Muhammad A \& Arshad F (2013). Trends in sunflower production and its potential in increasing domestic edible oil production in punjab, Pakistan. Sarhad J Agric 29(1): 7-13.

2. Hanif M (2014). Weather prediction past, present and future in KP and Punjab. Report presented to IC Peshawar. National weather Forecasting center (PMD) Islamabad

3. Pakistan Oil Seed, and Products Annual Reports (2013). pp. 233-235.

4. Hussain TI \& Ahmed MA (2000). EM Technology-A new look for IPNM. In: Proc. 
Symp., Integrated Plant Nutrient Management, NFDC, Islamabad, Pakistan.

5. Murthy BC, Prathibha NC \& Thammaiah N (1995). Studies on alleloapthic effect of parthenium on sunflower and sorghum. World Weeds 2: 161-164.

6. Alipour S, Farshadfar E \& Binesh S (2012). Allelopathic effects of Yarrow (Achilla millefalium) on the weeds of corn (Zea mays L.). Eur J of Exp Biol 2(6): 2493-2498.

7. Baloglu CM, Kavas M, Aydin G, Oktem HA \& Yücel AM (2012). Antioxidative and physiological responses of two sunflower (Helianthus annuus) cultivars under PEGmediated drought stress. Turk J Bot 36(4): 707-714.

8. Kakar MA, Abdul WB, Jay KS, Naila G, Muhammad SC, Ghulam FKK, Ameena J, Ayaz LS, Amanullah M \& Usman AK (2021). Assessment of genetic divergence and character association in upland cotton (gossypium hirsutum 1.) Genotypes. Int $J$ Biol Biotech 18(2): 321-327

9. Butnariu M (2012). An analysis of Sorghum halepense's behavior in presence of tropane alkaloids from Datura stramonium extracts. Chem C J 6: 75-79.

10. Hesammi E (2011). The Allopathic effects of Sorghum halepense and Amaranthus retroflexsus extract on the Germination of Corn Grain. Aust J of Basic and Appl Sci 5(9): 2249-2253.

11. Iqbal M, Anwar T \& Ghafoor O (2009). The allelopathic potential of Jonsongrass Sorghum halepense (L.) Pers. to control some weed species. Mesopotamia J of Agric 10: 315-319.

12. Kohli RK, inghHP S \& Batish DR (2001). Allelopathy in agroecosystem. $J$ of Crop Produc 8: 4-2.

13. Kong CH, Hu F, Wang P \&. Wu JL (2008). Effect of allelopathic rice varieties combined with cultural management options on paddy field weeds. Pest Manag Sci 64: 276-282.

14. Mahmood A, Rashid A, Ali MA \& Waqar MQ (2013). Efficacy of aqueous extracts of different allelopathic plants combined with reduced herbicide doses for weed control in wheat. J Agric Res 51(4): 353-357.

15. Mudassir R, Ishaque M, Abbas G, Khokhar MB \& Amer M (2013). Evaluation of combined application of allelopathic crop leachates and post-emergence herbicide for control of weeds in rice (Oryza Sativa L.) crop. J of Plant Sci 90(3): 915-920.

16. Siyal AL, Fozia KS \& Tahira J (2021). Yield from genetic variability of bread wheat (Triticum aestivum L.) genotypes under water stress condition: A case study of Tandojam, Sindh. Pure \& Appl Biol 10(3): 841-860.

17. Newman D (1989). Grasslands: history and revegetation projects. Memo in grasslands file, TNC, Tucson A. http://wiki.bugwood.org/Sorghum_halepens $e$

18. Nouri H, Ansari TZ \& Abolfazl T (2012). Effect of weed allelopathic of sorghum (Sorghum halepense) on germination and seedling growth of wheat, Alvand cultivar. Ann of Biol Res 3(3): 1283.

19. Siyal AL, Ali GC, Nasiruddin S, Jay KS, Tahira J, Fozia KS \& Muhammad SC (2021). Screening of Wheat Genotypes for Morphological, Physiological and Phenological Traits Under Climatic Condition. Eur J of Biol \& Biotechnol 2(2): 87-91.

20. Sedigheh SR, Rahnavard A \& Ashrafi ZY (2010). Allelopathic effect of Helianthus annuus (sunflower) on Solanum nigrum (black nightshade) germination of seed and growth in laboratory condition. J of Hort Sci and Ornamental Plants 2: 32-37.

21. Siyal AL (2017). Effect of bio fertilizer in addition with phosphorus on the growth of maize (zeamayz L.). Inter $J$ of $A d v$ Res 5(12): 527-532.

22. Soufan R \& Almouemar A (2010). Allelopathic effects of some weeds on growth of maize (Zea mays L.). Proc $8^{\text {th }}$ Inter Conf on Biol Herbs, Syria. 